\title{
Duration of protection of BNT162b2 and mRNA-1273 COVID-19 vaccines against symptomatic SARS-CoV-2 Omicron infection in Qatar
}

Hiam Chemaitelly, $\mathrm{PhD}^{1,2,3}$, Houssein H. Ayoub, $\mathrm{PhD}^{4}$, Sawsan AlMukdad, MSc ${ }^{1,2}$, Patrick Tang, MD PhD ${ }^{5}$, Mohammad R. Hasan, $\mathrm{PhD}^{5}$, Hadi M. Yassine, $\mathrm{PhD}^{6,7}$ Hebah A. Al Khatib, $\mathrm{PhD}^{6,7}$, Maria K. Smatti, MSc ${ }^{6,7}$, Peter Coyle, $\mathrm{MD}^{6,8,9}$, Zaina Al Kanaani, $\mathrm{PhD}^{8}$, Einas Al Kuwari, $\mathrm{MD}^{8}$, Andrew Jeremijenko, $\mathrm{MD}^{8}$, Anvar Hassan Kaleeckal, MSc${ }^{8}$, Ali Nizar Latif, $\mathrm{MD}^{8}$, Riyazuddin Mohammad Shaik, MSc ${ }^{8}$, Hanan F. Abdul Rahim, $\mathrm{PhD}^{10}$, Gheyath K. Nasrallah, $\mathrm{PhD}^{6,7}$, Mohamed Ghaith Al Kuwari, MD ${ }^{11}$, Adeel A. Butt, MBBS MS ${ }^{3,8,12}$, Hamad Eid Al Romaihi, MD ${ }^{13}$, Mohamed H. Al-Thani, MD ${ }^{13}$, Abdullatif Al Khal, MD ${ }^{8}$, Roberto Bertollini, MD MPH ${ }^{13}$, and Laith J. Abu-Raddad, $\mathrm{PhD}^{1,2,3,10^{*}}$

${ }^{1}$ Infectious Disease Epidemiology Group, Weill Cornell Medicine-Qatar, Cornell University, Doha, Qatar

${ }^{2}$ World Health Organization Collaborating Centre for Disease Epidemiology Analytics on HIV/AIDS, Sexually Transmitted Infections, and Viral Hepatitis, Weill Cornell Medicine-Qatar, Cornell University, Qatar Foundation - Education City, Doha, Qatar

${ }^{3}$ Department of Population Health Sciences, Weill Cornell Medicine, Cornell University, New York, New York, USA

${ }^{4}$ Mathematics Program, Department of Mathematics, Statistics, and Physics, College of Arts and Sciences, Qatar University, Doha, Qatar

${ }^{5}$ Department of Pathology, Sidra Medicine, Doha, Qatar

${ }^{6}$ Biomedical Research Center, Member of QU Health, Qatar University, Doha, Qatar

${ }^{7}$ Department of Biomedical Science, College of Health Sciences, Member of QU Health, Qatar University, Doha, Qatar

${ }^{8}$ Hamad Medical Corporation, Doha, Qatar

${ }^{9}$ Wellcome-Wolfson Institute for Experimental Medicine, Queens University, Belfast, United Kingdom

${ }^{10}$ Department of Public Health, College of Health Sciences, Member of QU Health, Qatar University, Doha, Qatar

${ }^{11}$ Primary Health Care Corporation, Doha, Qatar

${ }^{12}$ Department of Medicine, Weill Cornell Medicine, Cornell University, New York, New York, USA

${ }^{13}$ Ministry of Public Health, Doha, Qatar

Word count: Abstract: 328 words, Main Text: 2,431 words.

Number of tables: 2

Number of figures: 1

*Correspondence to Professor Laith J. Abu-Raddad, E-mail: lja2002@qatar-med.cornell.edu. 
medRxiv preprint doi: https://doi.org/10.1101/2022.02.07.22270568; this version posted February 8, 2022. The copyright holder for this preprint (which was not certified by peer review) is the author/funder, who has granted medRxiv a license to display the preprint in perpetuity.

All rights reserved. No reuse allowed without permission.

\begin{abstract}
BACKGROUND: Qatar has been experiencing a large SARS-CoV-2 Omicron (B.1.1.529) wave that started on December 19, 2021. We assessed duration of protection of BNT162b2 (PfizerBioNTech) and mRNA-1273 (Moderna) COVID-19 vaccines after second dose and after third/booster dose against symptomatic Omicron infection and against COVID-19 hospitalization and death, between December 23, 2021 and February 2, 2022.
\end{abstract}

METHODS: Vaccine effectiveness was estimated using the test-negative, case-control study design, applying the same methodology used earlier to assess waning of BNT162b2 and mRNA1273 effectiveness in the same population during earlier infection waves.

RESULTS: BNT162b2 effectiveness against symptomatic Omicron infection was highest at $61.9 \%$ (95\% CI: 49.9-71.1\%) in the first month after the second dose, but then gradually declined and was at $10 \%$ or less starting from the $5^{\text {th }}$ month after the second dose. After the booster, effectiveness rapidly rebounded to peak at about $55 \%$ between $2-5$ weeks after the booster, but then started to decline again thereafter. Effectiveness against severe, critical, or fatal COVID-19 was maintained at $>70 \%$ after the second dose and at $>90 \%$ after the booster with no evidence for declining effectiveness over time. mRNA-1273 effectiveness against symptomatic Omicron infection was highest at $44.8 \%$ (95\% CI: 16.0-63.8\%) in the first three months after the second dose, before gradually declining to negligible levels thereafter. After the booster, effectiveness rapidly rebounded to peak at about 55\% between 2-5 weeks after the booster, but then declined again thereafter. Effectiveness against severe, critical, or fatal COVID-19 was high at $>60 \%$ after the second dose and at $>80 \%$ after the booster, but the confidence intervals were wide owing to the small number of cases. 
medRxiv preprint doi: https://doi.org/10.1101/2022.02.07.22270568; this version posted February 8, 2022. The copyright holder for this preprint (which was not certified by peer review) is the author/funder, who has granted medRxiv a license to display the preprint in perpetuity. All rights reserved. No reuse allowed without permission.

CONCLUSIONS: BNT162b2 and mRNA-1273 vaccines show a similar level and pattern of protection against symptomatic Omicron infection. Protection against Omicron is lower than that against Alpha, Beta, and Delta variants, and wanes more rapidly than against earlier variants after the second and booster doses. Meanwhile, protection against hospitalization and death appears robust and durable after both the second and booster doses. 
medRxiv preprint doi: https://doi.org/10.1101/2022.02.07.22270568; this version posted February 8, 2022. The copyright holder for this preprint (which was not certified by peer review) is the author/funder, who has granted medRxiv a license to display the preprint in perpetuity.

All rights reserved. No reuse allowed without permission.

\section{Introduction}

Qatar has been experiencing a large severe acute respiratory syndrome coronavirus 2 (SARSCoV-2) Omicron (B.1.1.529) ${ }^{1}$ wave that started on December 19, 2021 and peaked in midJanuary, 2022. 2,3 We assessed the duration of protection of BNT162b2 (Pfizer-BioNTech) and mRNA-1273 (Moderna) coronavirus disease 2019 (COVID-19) vaccines after second dose and after third/booster dose against symptomatic Omicron infection and against COVID-19 hospitalization and death, between December 23, 2021 and February 2, 2022.

\section{Methods}

\section{Study population, data sources, and study design}

This study was conducted in the resident population of Qatar, applying the same methodology that was used to assess waning of the BNT162b2 $2^{4}$ and mRNA-1273 ${ }^{5}$ COVID-19 vaccine effectiveness in the same population during earlier infection waves. A detailed description of this methodology can be found in Chemaitelly et al. ${ }^{4}$

COVID-19 laboratory testing, vaccination, clinical infection data, and related demographic details were extracted from the national, federated SARS-CoV-2 databases that include all polymerase chain reaction (PCR) testing, COVID-19 vaccinations, and COVID-19 hospitalizations and deaths in Qatar since the start of the pandemic.

Every PCR test conducted in Qatar is classified on the basis of symptoms and the reason for testing (clinical symptoms, contact tracing, surveys or random testing campaigns, individual requests, routine healthcare testing, pre-travel, at port of entry, or other). Qatar has unusually young, diverse demographics, in that only $9 \%$ of its residents are $\geq 50$ years of age, and $89 \%$ are expatriates from over 150 countries. ${ }^{6,7}$ Nearly all individuals were vaccinated in Qatar, but if 
medRxiv preprint doi: https://doi.org/10.1101/2022.02.07.22270568; this version posted February 8, 2022. The copyright holder for this preprint (which was not certified by peer review) is the author/funder, who has granted medRxiv a license to display the preprint in perpetuity.

All rights reserved. No reuse allowed without permission.

vaccinated elsewhere, those vaccinations were still recorded in the health system at the port of entry upon return to Qatar.

By February 2, 2022 (end of study), 1,301,203 individuals received $\geq 2$ BNT162b2 doses in Qatar, of whom 301,059 received a booster dose. Meanwhile, 891,810 individuals received $\geq 2$ mRNA-1273 doses, of whom 105,558 received a booster dose. The median dates of first, second, and third doses were May 3, 2021, May 24, 2021, and December 17, 2021 for BNT162b2, and May 28, 2021, June 27, 2021, and January 4, 2022 for mRNA-1273, respectively. The median time between the first and second dose was 21 days (interquartile range (IQR), 21-22 days) for BNT162b2 and 28 days (IQR, 28-30 days) for mRNA-1273, while that between second and booster dose was 250 days (IQR, 232-272 days) for BNT162b2 and 233 days (IQR, 212-254 days) for mRNA-1273.

Vaccine effectiveness during the large SARS-CoV-2 Omicron wave in Qatar, between December 23, 2021 and February 2, 2022, was estimated using the test-negative, case-control study design, a standard design for assessing vaccine effectiveness. ${ }^{8-16}$ Cases (PCR-positive persons) and controls (PCR-negative persons) were exact-matched two-to-one by sex, 10-year age group, nationality, and calendar week of PCR test to estimate effectiveness against symptomatic SARSCoV-2 Omicron infection. Symptomatic SARS-CoV-2 Omicron infection was defined as a PCRpositive swab collected during the Omicron wave because of clinical suspicion due to presence of symptoms compatible with a respiratory tract infection.

The two-to-one matching ratio was done to improve the statistical precision of the estimates. This specific matching ratio was dictated by the higher number of PCR-positive tests than PCRnegative tests during the large Omicron wave (Figure S1). Matching was performed to control for known differences in the risk of exposure to SARS-CoV-2 infection in Qatar. ${ }^{717-20}$ 
medRxiv preprint doi: https://doi.org/10.1101/2022.02.07.22270568; this version posted February 8, 2022. The copyright holder for this preprint (which was not certified by peer review) is the author/funder, who has granted medRxiv a license to display the preprint in perpetuity.

All rights reserved. No reuse allowed without permission.

Vaccine effectiveness was also estimated against any severe, critical, or fatal COVID-19 using the same methodology. Here, however, the matching ratio was one-to-five to improve the statistical precision given the relatively small number of severe, critical, and fatal COVID-19 cases during the Omicron wave.

Only the first PCR-positive test during the study was included for each case, whereas all PCRnegative tests during the study were included for each control. Controls included individuals with no record of a PCR-positive test during the study period. Only PCR tests conducted for clinical suspicion; that is due to presence of symptoms compatible with a respiratory tract infection, were included in the analysis. All persons who received a vaccine other than BNT162b2 or mRNA1273, or who received mixed vaccines, were excluded. These inclusion and exclusion criteria were implemented to minimize different types of potential bias based on earlier analyses in the same population. ${ }^{4,5}$ Every control that met the inclusion criteria and that could be matched to a case was included in the analysis. Both PCR-test outcomes and vaccination status were ascertained at the time of the PCR test.

Classification of COVID-19 case severity (acute-care hospitalizations), ${ }^{21}$ criticality (ICU hospitalizations), ${ }^{21}$ and fatality ${ }^{22}$ followed World Health Organization (WHO) guidelines, and assessments were made by trained medical personnel using individual chart reviews (Section S1). Each person who had a positive PCR test result and COVID-19 hospital admission was subject to an infection severity assessment every three days until discharge or death, regardless of the length of the hospital stay or the time between the PCR-positive test and the final disease outcome. Individuals who progressed to severe, ${ }^{21}{\text { critical },{ }^{21} \text { or fatal }}^{22}$ COVID-19 between the PCR-positive test result and the end of the study were classified based on their worst outcome, starting with death, followed by critical disease, and then severe disease. 
medRxiv preprint doi: https://doi.org/10.1101/2022.02.07.22270568; this version posted February 8, 2022. The copyright holder for this preprint (which was not certified by peer review) is the author/funder, who has granted medRxiv a license to display the preprint in perpetuity.

All rights reserved. No reuse allowed without permission.

\section{Laboratory methods}

Details of laboratory methods for real-time reverse-transcription PCR (RT-qPCR) testing and multiplex RT-qPCR variant screening are found in Section S2. All PCR testing was conducted at the Hamad Medical Corporation Central Laboratory or at Sidra Medicine Laboratory, following standardized protocols.

\section{Oversight}

Hamad Medical Corporation and Weill Cornell Medicine-Qatar Institutional Review Boards approved this retrospective study with waiver of informed consent. The study was reported following the STROBE guidelines. The STROBE checklist is found in Table S1.

\section{Statistical analysis}

All records of PCR testing in Qatar during the study were examined, but only samples of matched cases and controls that underwent PCR testing for clinical suspicion were included in the analysis. Demographic characteristics of study samples were described using frequency distributions and measures of central tendency. Study groups were compared using standardized mean differences (SMDs), defined as the difference in the mean of a covariate between groups divided by the pooled standard deviation. SMD $<0.1$ indicated adequate matching. ${ }^{23}$

The odds ratio, comparing odds of vaccination among cases versus controls, and its associated $95 \%$ confidence interval (CI) were derived using conditional logistic regression, that is factoring the matching in the study design. This matching and analysis approach aims to minimize potential bias due to variation in epidemic phase, ${ }^{8,24}$ gradual roll-out of vaccination during the study, ${ }^{8,24}$ or other confounders. ${ }^{25,26} 95 \%$ CIs were not adjusted for multiplicity and thus should not be used to infer definitive differences between different groups. Interactions were not 
medRxiv preprint doi: https://doi.org/10.1101/2022.02.07.22270568; this version posted February 8, 2022. The copyright holder for this preprint (which was not certified by peer review) is the author/funder, who has granted medRxiv a license to display the preprint in perpetuity.

All rights reserved. No reuse allowed without permission.

investigated. Vaccine effectiveness at different time points and its associated $95 \%$ CI were calculated by applying the following equation: 8,9

Vaccine effectiveness $=1$ - odds ratio of vaccination among cases versus controls .

In each analysis for a specific time-since-vaccination stratum, we included only those vaccinated in that specific time-since-vaccination stratum and those unvaccinated (our reference group). Only matched pairs of PCR-positive and PCR-negative persons, in which members of the pair were either unvaccinated or fell within each time-since-vaccination stratum were included in the corresponding vaccine effectiveness estimate. Thus, the number of cases (and controls) varied across time-since-vaccination analyses. Effectiveness after the second dose was estimated by one or more months where one month was defined as 30 days. Effectiveness after the third/booster dose was estimated by one or more weeks where one week was defined as 7 days.

\section{Results}

Figure S1 shows the process of selecting the study populations and Table S2 describes their demographic characteristics. The study was based on the total population of Qatar and thus the study population is broadly representative of the diverse, by national background, but young and predominantly male, total population of Qatar (Table S3).

BNT162b2 effectiveness against symptomatic Omicron infection was highest at $61.9 \%$ (95\% CI: 49.9-71.1\%) in the first month after the second dose, but then gradually declined and was at $10 \%$ or less starting from the $5^{\text {th }}$ month after the second dose (Figure 1 and Table 1). After the booster, effectiveness rapidly rebounded to peak at about $55 \%$ between $2-5$ weeks after the booster, but then started to decline again thereafter. Effectiveness against severe, critical, or fatal 
medRxiv preprint doi: https://doi.org/10.1101/2022.02.07.22270568; this version posted February 8, 2022. The copyright holder for this preprint (which was not certified by peer review) is the author/funder, who has granted medRxiv a license to display the preprint in perpetuity.

All rights reserved. No reuse allowed without permission.

COVID-19 was maintained at $>70 \%$ after the second dose and at $>90 \%$ after the booster with no evidence for declining effectiveness over time (Figure 1 and Table 2).

mRNA-1273 effectiveness against symptomatic Omicron infection was highest at 44.8\% (95\% CI: $16.0-63.8 \%)$ in the first three months after the second dose, before gradually declining to negligible levels thereafter (Figure 1 and Table 1). After the booster, effectiveness rapidly rebounded to peak at about $55 \%$ between 2-5 weeks after the booster, but then declined again thereafter. Effectiveness against severe, critical, or fatal COVID-19 was high at $>60 \%$ after the second dose and at $>80 \%$ after the booster, but the confidence intervals were wide owing to the small number of cases (Table 2).

\section{Discussion and conclusions}

BNT162b2 and mRNA-1273 vaccines show a similar level and pattern of protection against symptomatic Omicron infection. Protection against Omicron is lower than that against Alpha, Beta, and Delta variants, ${ }^{4,5,14}$ and wanes more rapidly than against earlier variants after the second and booster doses. ${ }^{4,5}$ However, the waning appears slower after the booster compared to after the second dose. Meanwhile, protection against hospitalization and death appears robust and durable after both the second and booster doses.

\section{$\underline{\text { Caveats and limitations }}$}

Since the immunization campaigns prioritized vaccination of persons with severe or multiple chronic conditions and by age group, the observed pattern of waning of protection could theoretically be confounded by effects of age and comorbidities. Individual-level data on comorbid conditions were not available; therefore, they could not be explicitly factored into our analysis. However, only a small proportion of the study population may have had serious co- 
medRxiv preprint doi: https://doi.org/10.1101/2022.02.07.22270568; this version posted February 8, 2022. The copyright holder for this preprint (which was not certified by peer review) is the author/funder, who has granted medRxiv a license to display the preprint in perpetuity.

All rights reserved. No reuse allowed without permission.

morbid conditions. Only $9 \%$ of the population of Qatar are $\geq 50$ years of age, ${ }^{6,7}$ and $60 \%$ are young, expatriate craft and manual workers working in mega-development projects. ${ }^{19,20,27}$ The national list of persons prioritized to receive the vaccine during the first phase of vaccine roll-out included only 19,800 individuals of all age groups with serious co-morbid conditions. Old age may serve as a partial proxy for co-morbid conditions. A similar pattern of waning of protection was observed for younger and older persons in our earlier waning of vaccine effectiveness studies for the same population. ${ }^{4,5}$ However, with the small proportion of Qatar's population being $\geq 50$ years of age, ${ }^{6,7}$ our findings may not be generalizable to other countries in which elderly citizens constitute a larger proportion of the total population.

Vaccinated persons presumably have a higher social contact rate than unvaccinated persons, and they may also adhere less strictly to safety measures. ${ }^{28-30}$ This behavior could reduce real-world effectiveness of the vaccine compared to its biological effectiveness, possibly explaining the waning of protection. Public health restrictions in Qatar were eased gradually, but differently for vaccinated and unvaccinated persons. Many social, work, and travel activities presently require evidence of vaccination (a "health pass") that is administered through a mandatory mobile app (the Ehteraz app). However, risk compensation is unlikely to solely explain the observed waning of protection over time.

PCR testing in Qatar is done on a mass scale, such that about $5 \%$ of the population are tested every week. ${ }^{4}$ With the large demand for testing during the Omicron wave, use of rapid antigen testing (RAT) was expanded to supplement PCR testing at health care facilities starting from January 5, 2022, but information on reason for testing was not available for the RAT testing to be included in our study. 
Effectiveness was assessed using an observational, test-negative, case-control study design, ${ }^{8,9}$ rather than a design in which cohorts of vaccinated and unvaccinated individuals were followed up. However, the cohort study design applied earlier to the same population of Qatar yielded findings similar to those of the test-negative case-control design, ${ }^{13-16}$ supporting the validity of this standard approach in assessing vaccine effectiveness for respiratory tract infections. ${ }^{8-16}$ Moreover, our recent study of the effectiveness of booster vaccination against SARS-CoV-2 symptomatic infection, relative to that of the primary series, used a cohort study design ${ }^{3}$ and its results are consistent with the results generated in the present study using the test-negative, casecontrol study design.

With the high COVID-19 vaccine coverage in Qatar (>80\%), the majority of those unvaccinated were children or young persons, and thus the reference group of those unvaccinated is not representative of the total population demographics. However, matching by age was implemented in all analyses to minimize potential bias arising from the young population structure of those unvaccinated.

To rapidly scale up vaccination, some vaccination campaigns are conducted outside healthcare facilities; thus, records of vaccination are not immediately uploaded into the CERNER system, which tracks all vaccination records at the national level. This administrative time delay can introduce a misclassification bias of those vaccinated versus those unvaccinated. A sensitivity analysis investigating the impact of such potential bias, by assuming a $10 \%$ misclassification bias of those vaccinated, found a difference of, at most, few percentage points in estimated effectiveness..$^{5}$ A key strength of the test-negative, case-control study design is that it is less susceptible to this form of bias..$^{8,9}$ 
medRxiv preprint doi: https://doi.org/10.1101/2022.02.07.22270568; this version posted February 8, 2022. The copyright holder for this preprint (which was not certified by peer review) is the author/funder, who has granted medRxiv a license to display the preprint in perpetuity.

All rights reserved. No reuse allowed without permission.

Nonetheless, one cannot exclude the possibility that in real-world data, bias could arise in unexpected ways, or from unknown sources, such as subtle differences in test-seeking behavior or changes in the pattern of testing with introduction of other testing modalities, such as RAT. For example, with the large Omicron wave in Qatar, use of RAT was expanded to supplement PCR testing starting from January 5, 2022. However, RAT was broadly implemented in the population and thus may not have differentially affected PCR testing to introduce bias.

With the small number of PCR-positive symptomatic infections in some of the time-sincevaccination strata for those vaccinated with mRNA-1273, it was not possible to estimate mRNA1273 effectiveness month-by-month after the second dose. Furthermore, with the relatively small number of cases and controls that progressed to severe, critical, or fatal COVID-19 during the Omicron wave, confidence intervals for vaccine effectiveness against hospitalization and death were either very wide or could not be estimated, especially so for the mRNA-1273 analyses.

Notwithstanding these limitations, consistent findings were reached indicating rapid waning of vaccine protection against symptomatic Omicron infection that are broadly consistent with findings of other studies. ${ }^{31-39}$ Moreover, with the mass scale of PCR testing in Qatar, ${ }^{4}$ the likelihood of bias is perhaps minimized. Extensive sensitivity and additional analyses were conducted to investigate effects of potential bias in our earlier studies for the BNT162b2 $2^{4}$ and mRNA- $1273^{5}$ vaccines, which used the same methodology as the present study. These included different adjustments in the analysis, different approaches for factoring prior infection in the analysis, and different study inclusion and exclusion criteria to investigate whether the effectiveness estimates could have been biased. ${ }^{4,5}$ All analyses showed consistent findings. ${ }^{4,5}$ 
medRxiv preprint doi: https://doi.org/10.1101/2022.02.07.22270568; this version posted February 8, 2022. The copyright holder for this preprint (which was not certified by peer review) is the author/funder, who has granted medRxiv a license to display the preprint in perpetuity.

All rights reserved. No reuse allowed without permission.

\section{Acknowledgements}

We acknowledge the many dedicated individuals at Hamad Medical Corporation, the Ministry of Public Health, the Primary Health Care Corporation, the Qatar Biobank, Sidra Medicine, and Weill Cornell Medicine - Qatar for their diligent efforts and contributions to make this study possible.

The authors are grateful for support from the Biomedical Research Program and the Biostatistics, Epidemiology, and Biomathematics Research Core, both at Weill Cornell Medicine-Qatar, as well as for support provided by the Ministry of Public Health, Hamad Medical Corporation, and Sidra Medicine. The authors are also grateful for the Qatar Genome Programme and Qatar University Biomedical Research Center for institutional support for the reagents needed for the viral genome sequencing. Statements made herein are solely the responsibility of the authors. The funders of the study had no role in study design, data collection, data analysis, data interpretation, or writing of the article.

\section{Author contributions}

$\mathrm{HC}$ co-designed the study, performed the statistical analyses, and co-wrote the first draft of the article. LJA conceived and co-designed the study, led the statistical analyses, and co-wrote the first draft of the article. PT and MRH conducted the multiplex, RT-qPCR variant screening and viral genome sequencing. HY, HAK, and MKS conducted viral genome sequencing. All authors contributed to data collection and acquisition, database development, discussion and interpretation of the results, and to the writing of the manuscript. All authors have read and approved the final manuscript.

\section{Competing interests}


medRxiv preprint doi: https://doi.org/10.1101/2022.02.07.22270568; this version posted February 8, 2022. The copyright holder for this preprint

(which was not certified by peer review) is the author/funder, who has granted medRxiv a license to display the preprint in perpetuity.

All rights reserved. No reuse allowed without permission.

Dr. Butt has received institutional grant funding from Gilead Sciences unrelated to the work

presented in this paper. Otherwise, we declare no competing interests. 
medRxiv preprint doi: https://doi.org/10.1101/2022.02.07.22270568; this version posted February 8, 2022. The copyright holder for this preprint (which was not certified by peer review) is the author/funder, who has granted medRxiv a license to display the preprint in perpetuity.

All rights reserved. No reuse allowed without permission.

\section{References}

1. World Health Organization. Tracking SARS-CoV-2 variants. Available from: https://www.who.int/en/activities/tracking-SARS-CoV-2-variants/. 2021.

2. Altarawneh $\mathrm{H}$, Chemaitelly $\mathrm{H}$, Tang $\mathrm{P}$, et al. Protection afforded by prior infection against SARS-CoV-2 reinfection with the Omicron variant. medRxiv In press at New England Journal of Medicine 2022:2022.01.05.22268782.

3. Abu-Raddad LJ, Chemaitelly H, Ayoub HH, et al. Effectiveness of BNT162b2 and mRNA-1273 COVID-19 boosters against SARS-CoV-2 Omicron (B.1.1.529) infection in Qatar. medRxiv 2022:2022.01.18.22269452.

4. Chemaitelly H, Tang P, Hasan MR, et al. Waning of BNT162b2 Vaccine Protection against SARS-CoV-2 Infection in Qatar. N Engl J Med 2021;385:e83.

5. Abu-Raddad LJ, Chemaitelly H, Bertollini R. Waning mRNA-1273 Vaccine Effectiveness against SARS-CoV-2 Infection in Qatar. New England Journal of Medicine 2022.

6. Planning and Statistics Authority-State of Qatar. Qatar Monthly Statistics. Available from: https://www.psa.gov.qa/en/pages/default.aspx. Accessed on: May 26, 2020. 2020.

7. Abu-Raddad LJ, Chemaitelly H, Ayoub HH, et al. Characterizing the Qatar advancedphase SARS-CoV-2 epidemic. Sci Rep 2021;11:6233.

8. Jackson ML, Nelson JC. The test-negative design for estimating influenza vaccine effectiveness. Vaccine 2013;31:2165-8.

9. Verani JR, Baqui AH, Broome CV, et al. Case-control vaccine effectiveness studies: Preparation, design, and enrollment of cases and controls. Vaccine 2017;35:3295-302.

10. Sheikh A, McMenamin J, Taylor B, Robertson C. SARS-CoV-2 Delta VOC in Scotland: demographics, risk of hospital admission, and vaccine effectiveness. The Lancet 2021;397:24612.

11. Nasreen S, He S, Chung H, et al. Effectiveness of COVID-19 vaccines against variants of concern, Canada. medRxiv 2021:2021.06.28.21259420.

12. Lopez Bernal J, Andrews N, Gower C, et al. Effectiveness of Covid-19 Vaccines against the B.1.617.2 (Delta) Variant. N Engl J Med 2021;385:585-94.

13. Coyle PV, Kahlout RAE, Dargham SR, et al. Assessing the performance of a serological point-of-care test in measuring detectable antibodies against SARS-CoV-2. medRxiv 2021:2021.02.04.21251126.

14. Chemaitelly H, Yassine HM, Benslimane FM, et al. mRNA-1273 COVID-19 vaccine effectiveness against the B.1.1.7 and B.1.351 variants and severe COVID-19 disease in Qatar. Nat Med 2021;27:1614-21.

15. Butt AA, Chemaitelly $\mathrm{H}, \mathrm{Al}$ Khal A, et al. SARS-CoV-2 vaccine effectiveness in preventing confirmed infection in pregnant women. J Clin Invest 2021;131.

16. Tang P, Hasan MR, Chemaitelly H, et al. BNT162b2 and mRNA-1273 COVID-19 vaccine effectiveness against the SARS-CoV-2 Delta variant in Qatar. Nat Med 2021.

17. Ayoub HH, Chemaitelly H, Seedat S, et al. Mathematical modeling of the SARS-CoV-2 epidemic in Qatar and its impact on the national response to COVID-19. J Glob Health 2021;11:05005.

18. Coyle PV, Chemaitelly H, Ben Hadj Kacem MA, et al. SARS-CoV-2 seroprevalence in the urban population of Qatar: An analysis of antibody testing on a sample of 112,941 individuals. iScience 2021;24:102646. 
medRxiv preprint doi: https://doi.org/10.1101/2022.02.07.22270568; this version posted February 8, 2022. The copyright holder for this preprint (which was not certified by peer review) is the author/funder, who has granted medRxiv a license to display the preprint in perpetuity.

All rights reserved. No reuse allowed without permission.

19. Chemaitelly H, Yassine HM, Benslimane FM, et al. mRNA-1273 COVID-19 vaccine effectiveness against the B.1.1.7 and B.1.351 variants and severe COVID-19 disease. 2021:Submitted.

20. Jeremijenko A, Chemaitelly H, Ayoub HH, et al. Herd Immunity against Severe Acute Respiratory Syndrome Coronavirus 2 Infection in 10 Communities, Qatar. Emerg Infect Dis 2021;27:1343-52.

21. World Health Organization. COVID-19 clinical management: living guidance. Available from: https://www.who.int/publications/i/item/WHO-2019-nCoV-clinical-2021-1. Accessed on: May 31, 2021. 2021.

22. World Health Organization. International guidelines for certification and classification (coding) of COVID-19 as cause of death. Available from:

https://www.who.int/classifications/icd/Guidelines_Cause_of_Death_COVID-19-20200420EN.pdf?ua=1. Document Number: WHO/HQ/DDI/DNA/CAT. Accessed on May 31, 2021. 2021.

23. Austin PC. Using the Standardized Difference to Compare the Prevalence of a Binary Variable Between Two Groups in Observational Research. Communications in Statistics Simulation and Computation 2009;38:1228-34.

24. Jacoby P, Kelly H. Is it necessary to adjust for calendar time in a test negative design?: Responding to: Jackson ML, Nelson JC. The test negative design for estimating influenza vaccine effectiveness. Vaccine 2013;31(April (17)):2165-8. Vaccine 2014;32:2942.

25. $\quad$ Pearce N. Analysis of matched case-control studies. BMJ 2016;352:1969.

26. Rothman KJ, Greenland S, Lash TL. Modern epidemiology. 3rd ed. Philadelphia:

Wolters Kluwer Health/Lippincott Williams \& Wilkins; 2008.

27. Planning and Statistics Authority- State of Qatar. Labor force sample survey. Available from:

https://www.psa.gov.qa/en/statistics/Statistical\%20Releases/Social/LaborForce/2017/statistical_a nalysis_labor_force_2017_En.pdf. Accessed on: May 01, 2020. 2017.

28. Makhoul M., Ayoub H.H., Chemaitelly H., et al. Epidemiological impact of SARS-CoV2 vaccination: Mathematical modeling analyses. Vaccines 2020;8.

29. Usherwood T, LaJoie Z, Srivastava V. A model and predictions for COVID-19 considering population behavior and vaccination. Scientific Reports 2021;11:12051.

30. Andersson O, Campos-Mercade P, Meier AN, Wengström E. Anticipation of COVID-19 Vaccines Reduces Social Distancing. https://papers.ssrn.com/sol3/papers.cfm?abstract_id=3765329. SSRN 2021.

31. Andrews N, Stowe J, Kirsebom F, et al. Effectiveness of COVID-19 vaccines against the Omicron (B.1.1.529) variant of concern. medRxiv 2021:2021.12.14.21267615.

32. Tseng HF, Ackerson BK, Luo Y, et al. Effectiveness of mRNA-1273 against SARSCoV-2 omicron and delta variants. medRxiv 2022:2022.01.07.22268919.

33. Buchan SA, Chung H, Brown KA, et al. Effectiveness of COVID-19 vaccines against Omicron or Delta infection. medRxiv 2022:2021.12.30.21268565.

34. Hansen CH, Schelde AB, Moustsen-Helm IR, et al. Vaccine effectiveness against SARSCoV-2 infection with the Omicron or Delta variants following a two-dose or booster BNT162b2 or mRNA-1273 vaccination series: A Danish cohort study. medRxiv 2021:2021.12.20.21267966. 35. Sheikh A, Kerr S, Woolhouse M, McMenamin J, Robertson C. Severity of Omicron variant of concern and vaccine effectiveness against symptomatic disease: national cohort with nested test negative design study in Scotland. Availablble at 
medRxiv preprint doi: https://doi.org/10.1101/2022.02.07.22270568; this version posted February 8, 2022. The copyright holder for this preprint (which was not certified by peer review) is the author/funder, who has granted medRxiv a license to display the preprint in perpetuity.

All rights reserved. No reuse allowed without permission.

https://www.research.ed.ac.uk/en/publications/severity-of-omicron-variant-of-concern-andvaccine-effectiveness-. Preprint accessed on January 12, 2021. 2021.

36. Willett BJ, Grove J, MacLean OA, et al. The hyper-transmissible SARS-CoV-2 Omicron variant exhibits significant antigenic change, vaccine escape and a switch in cell entry mechanism. medRxiv 2022:2022.01.03.21268111.

37. Thompson MG, Natarajan K, Irving SA, et al. Effectiveness of a Third Dose of mRNA Vaccines Against COVID-19-Associated Emergency Department and Urgent Care Encounters and Hospitalizations Among Adults During Periods of Delta and Omicron Variant Predominance - VISION Network, 10 States, August 2021-January 2022. MMWR Morb Mortal Wkly Rep 2022;71:139-45.

38. Tartof SY, Slezak JM, Puzniak L, et al. BNT162b2 (Pfizer-BioNTech) mRNA COVID19 vaccine against omicron-related hospital 2 and emergency department admission in a large US health system: a test-negative design. SSRN Electronic Journal 2022.

39. Kislaya I, Peralta-Santos A, Borges V, et al. Comparative complete scheme and booster effectiveness of COVID-19 vaccines in preventing SARS-CoV-2 infections with SARS-CoV-2 Omicron (BA.1) and Delta (B.1.617.2) variants. medRxiv 2022:2022.01.31.22270200. 
medRxiv preprint doi: https://doi.org/10.1101/2022.02.07.22270568; this version posted February 8, 2022. The copyright holder for this preprint (which was not certified by peer review) is the author/funder, who has granted medRxiv a license to display the preprint in perpetuity.

Figure 1. Effectiveness of the BNT162b2 vaccine against A) symptomatic SARS-CoV-2 Omicron infection and B) severe, critical, or fatal COVID-19 due to Omicron infection. C) Effectiveness of the mRNA-1273 vaccine against symptomatic SARS-CoV-2 Omicron infection. Data are presented as effectiveness point estimates. Error bars indicate the corresponding $95 \%$ confidence intervals.
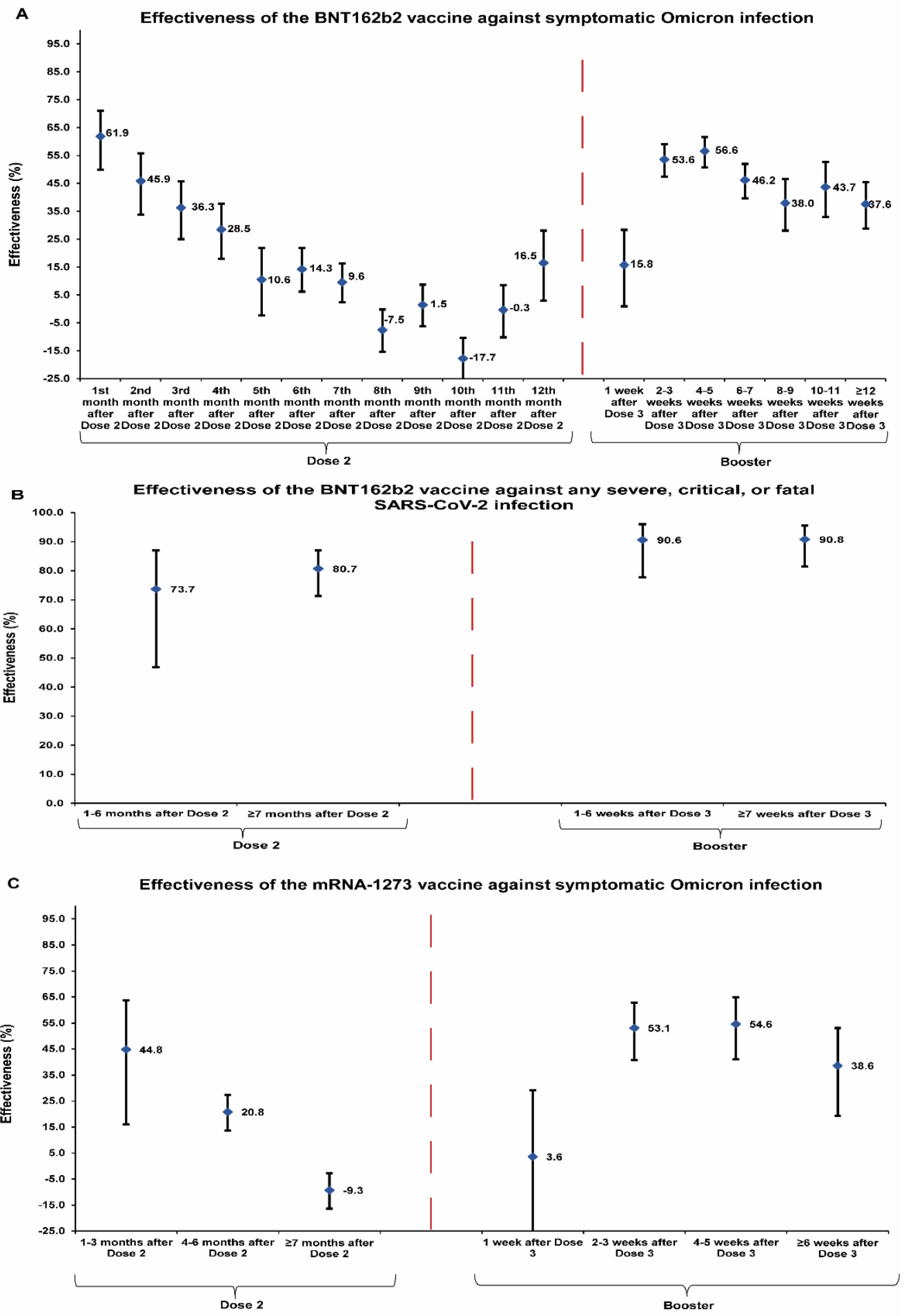

The time-since-vaccination categories were chosen to maximize statistical precision in each analysis as the number of cases was small for some of the time-since-vaccination strata. Therefore, the time-since-vaccination categories were different for the BNT162b2 and mRNA-1273 analyses and for the analysis against any severe, critical, or fatal COVID-19. 
Table 1. Effectiveness of the BNT162b2 and mRNA-1273 vaccines against symptomatic SARS-CoV-2 Omicron infection**

\begin{tabular}{|c|c|c|c|c|c|}
\hline \multirow[t]{2}{*}{ Sub-studies $^{\dagger}$} & \multicolumn{2}{|c|}{$\begin{array}{c}\text { Cases }^{\ddagger} \\
\text { (PCR-positive) }\end{array}$} & \multicolumn{2}{|c|}{$\begin{array}{c}\text { Controls } \\
\text { (PCR-negative) }\end{array}$} & \multirow{2}{*}{$\begin{array}{c}\text { Effectiveness in \% } \\
(\mathbf{9 5 \%} \mathrm{CI})^{\S}\end{array}$} \\
\hline & Vaccinated & Unvaccinated & Vaccinated & Unvaccinated & \\
\hline \multicolumn{6}{|l|}{ BNT162b2 } \\
\hline \multicolumn{6}{|l|}{ Dose 1} \\
\hline $0-13$ days after Dose 1 & 60 & 12,866 & 37 & 7,781 & $-7.2(-40.3$ to 38.6$)$ \\
\hline$\geq 14$ days after Dose 1 and no Dose 2 & 155 & 12,889 & 127 & 7,784 & $26.1(5.8$ to 42.0$)$ \\
\hline \multicolumn{6}{|l|}{ Dose 2} \\
\hline $1^{\text {st }}$ month after Dose 2 and no Dose 3 & 90 & 12,952 & 134 & 7,777 & $61.9(49.9$ to 71.1$)$ \\
\hline $2^{\text {nd }}$ month after Dose 2 and no Dose 3 & 207 & 13,009 & 209 & 7,802 & $45.9(33.8$ to 55.8$)$ \\
\hline $3^{\text {rd }}$ month after Dose 2 and no Dose 3 & 340 & 13,075 & 302 & 7,797 & $36.3(25.1$ to 45.8$)$ \\
\hline $4^{\text {th }}$ month after Dose 2 and no Dose 3 & 524 & 13,072 & 410 & 7,799 & $28.5(18.0$ to 37.8$)$ \\
\hline $5^{\text {th }}$ month after Dose 2 and no Dose 3 & 622 & 12,981 & 403 & 7,811 & $10.6(-2.3$ to 21.9$)$ \\
\hline $6^{\text {th }}$ month after Dose 2 and no Dose 3 & 1,510 & 13,087 & 987 & 7,816 & $14.3(6.2$ to 21.8$)$ \\
\hline $7^{\text {th }}$ month after Dose 2 and no Dose 3 & 2,425 & 13,238 & 1,529 & 7,894 & $9.6(2.4$ to 16.3$)$ \\
\hline $8^{\text {th }}$ month after Dose 2 and no Dose 3 & 3,625 & 13,026 & 2,003 & 7,915 & $-7.5(-15.3$ to -0.2$)$ \\
\hline $9^{\text {th }}$ month after Dose 2 and no Dose 3 & 2,989 & 13,134 & 1,779 & 7,901 & $1.5(-6.2$ to 8.7$)$ \\
\hline $10^{\text {th }}$ month after Dose 2 and no Dose 3 & 6,257 & 12,946 & 3,340 & 7,974 & $-17.7(-25.6$ to -10.3$)$ \\
\hline $11^{\text {th }}$ month after Dose 2 and no Dose 3 & 2,335 & 13,045 & 1,337 & 7,867 & $-0.3(-10.2$ to 8.6$)$ \\
\hline$\geq 12^{\text {th }}$ month after Dose 2 and no Dose 3 & 614 & 12,984 & 415 & 7,811 & $16.5(3.1$ to 28.1$)$ \\
\hline \multicolumn{6}{|l|}{ Dose 3 (booster dose) } \\
\hline 1 week after Dose 3 & 403 & 12,945 & 281 & 7,800 & $15.8(0.9$ to 28.4$)$ \\
\hline 2-3 weeks after Dose 3 & 603 & 13,238 & 703 & 7,775 & $53.6(47.4$ to 59.1$)$ \\
\hline 4-5 weeks after Dose 3 & 666 & 13,304 & 771 & 7,772 & $56.6(50.8$ to 61.7$)$ \\
\hline 6-7 weeks after Dose 3 & 949 & 13,325 & 888 & 7,793 & $46.2(39.7$ to 52.0$)$ \\
\hline 8-9 weeks after Dose 3 & 521 & 13,082 & 470 & 7,797 & $38.0(28.1$ to 46.5$)$ \\
\hline 10-11 weeks after Dose 3 & 334 & 13,068 & 328 & 7,816 & $43.7(32.9$ to 52.7$)$ \\
\hline$\geq 12$ weeks after Dose 3 & 719 & 13,139 & 618 & 7,811 & $37.6(28.8$ to 45.4$)$ \\
\hline \multicolumn{6}{|l|}{ mRNA-1273 } \\
\hline \multicolumn{6}{|l|}{ Dose 1} \\
\hline $0-13$ days after Dose 1 & 19 & 12,761 & 10 & 7,709 & $-13.6(-146.4$ to 47.6$)$ \\
\hline$\geq 14$ days after Dose 1 and no Dose 2 & 58 & 12,763 & 36 & 7,707 & $-1.6(-56.8$ to 34.1$)$ \\
\hline \multicolumn{6}{|l|}{ Dose 2} \\
\hline $1-3$ months after Dose 2 and no Dose 3 & 44 & 12,797 & 46 & 7,708 & $44.8(16.0$ to 63.8$)$ \\
\hline 4-6 months after Dose 2 and no Dose 3 & 1,924 & 13,137 & 1,363 & 7,755 & $20.8(13.7$ to 27.4$)$ \\
\hline$\geq 7$ months after Dose 2 and no Dose 3 & 6,243 & 12,980 & 3,477 & 7,922 & $-9.3(-16.3$ to -2.8$)$ \\
\hline \multicolumn{6}{|l|}{ Dose 3 (booster dose) } \\
\hline 1 week after Dose 3 & 114 & 12,770 & 70 & 7,708 & $3.6(-31.0$ to 29.1$)$ \\
\hline 2-3 weeks after Dose 3 & 149 & 12,873 & 182 & 7,708 & $53.1(40.7$ to 62.8$)$ \\
\hline 4-5 weeks after Dose 3 & 117 & 12,861 & 146 & 7,699 & $54.6(41.1$ to 65.0$)$ \\
\hline$\geq 6$ weeks after Dose 3 & 117 & 12,828 & 110 & 7,712 & $38.6(19.4$ to 53.1$)$ \\
\hline
\end{tabular}

Abbreviations: CI, confidence interval; PCR, polymerase chain reaction

A symptomatic infection was defined as a PCR-positive nasopharyngeal swab conducted because of clinical suspicion due to presence of symptoms compatible with a respiratory tract infection.

In each analysis for a specific time-since-vaccination stratum, we included only those vaccinated in this specific time-since-vaccination stratum and those unvaccinated. Only matched pairs of PCR-positive and PCR-negative persons, in which both members of the pair were either unvaccinated or fell within each time-since-vaccination stratum have been included in the corresponding vaccine effectiveness estimate. Thus, the number of cases (and controls) varied across time-since-vaccination analyses. 
${ }^{\ddagger}$ Cases and controls were matched two-to-one by sex, 10-year age group, nationality, and calendar week of PCR test.

${ }^{8}$ Vaccine effectiveness was estimated using the test-negative, case-control study design., ${ }^{8,9}$ 
Table 2. Effectiveness of the BNT162b2 and mRNA-1273 vaccines against any severe, critical, or fatal COVID-19.

\begin{tabular}{|c|c|c|c|c|c|c|c|c|c|c|}
\hline \multirow{4}{*}{ Sub-studies ${ }^{*}$} & \multicolumn{5}{|c|}{ BNT162b2 } & \multicolumn{5}{|c|}{ mRNA-1273 } \\
\hline & \multirow{2}{*}{\multicolumn{2}{|c|}{$\begin{array}{c}\text { Cases }^{\dagger} \\
\begin{array}{c}\text { (Severe, critical, or } \\
\text { fatal disease) }\end{array} \\
\text { Vaccinated }\end{array}$}} & \multirow{2}{*}{\multicolumn{2}{|c|}{$\begin{array}{c}\begin{array}{c}\text { Controls }^{\dagger} \\
\text { (PCR-negative) }\end{array} \\
\text { Vaccinated }\end{array}$}} & \multirow[t]{3}{*}{$\begin{array}{c}\text { Effectiveness in \% } \\
(\mathbf{9 5 \%} \mathrm{CI})^{\S}\end{array}$} & \multirow{2}{*}{\multicolumn{2}{|c|}{$\begin{array}{c}\text { Cases }^{\dagger} \\
\left.\text { (Severe, critical, or }^{\text {(atal disease) }}\right)^{\ddagger} \\
\text { Vaccinated }\end{array}$}} & \multirow{2}{*}{\multicolumn{2}{|c|}{$\begin{array}{c}\begin{array}{c}\text { Controls }^{\dagger} \\
\text { (PCR-negative) }\end{array} \\
\text { Vaccinated }\end{array}$}} & \multirow{3}{*}{$\begin{array}{c}\text { Effectiveness in \% } \\
(95 \% \mathrm{CI})^{\S}\end{array}$} \\
\hline & & & & & & & & & & \\
\hline & Yes & No & Yes & No & & Yes & No & Yes & No & \\
\hline \multicolumn{11}{|l|}{ Dose 1} \\
\hline Dose 1 and no Dose 2 & 2 & 105 & 10 & 280 & $46.8(-1.6$ to 89.2$)$ & 0 & 103 & 2 & 280 & $100.0(\text { Omitted })^{\mathrm{II}}$ \\
\hline \multicolumn{11}{|l|}{ Dose 2} \\
\hline $1-6$ months after Dose 2 and no Dose 3 & 10 & 112 & 99 & 254 & $73.7(46.8$ to 87.0$)$ & 3 & 105 & 35 & 265 & $76.9(19.2$ to 93.4$)$ \\
\hline$\geq 7$ months after Dose 2 and no Dose 3 & 71 & 134 & 445 & 209 & $80.7(71.3$ to 87.0$)$ & 23 & 117 & 139 & 257 & $64.0(39.1$ to 78.7$)$ \\
\hline \multicolumn{11}{|l|}{ Dose 3 (booster dose) } \\
\hline 1-6 weeks after Dose 3 & 7 & 115 & 140 & 238 & $90.6(77.8$ to 96.0$)$ & 1 & 103 & 19 & 270 & $80.8(-51.9$ to 97.6$)$ \\
\hline$\geq 7$ weeks after Dose 3 & 12 & 125 & 199 & 230 & $90.8(81.5$ to 95.5$)$ & 0 & 102 & 5 & 278 & $100.0(\text { Omitted })^{\mathrm{II}}$ \\
\hline \multicolumn{11}{|c|}{$\begin{array}{l}\text { "In each analysis for a specific time-since-vaccination stratum, we included only those vaccinated in this specific time-since-vaccination stratum and those unvaccinated. Only matched pairs of PCR-positive and PCR-negative } \\
\text { persons, in which both members of the pair were either unvaccinated or fell within each time-since-vaccination stratum have been included in the corresponding vaccine effectiveness estimate. Thus, the number of cases (and } \\
\text { controls) varied across time-since-vaccination analyses. }\end{array}$} \\
\hline
\end{tabular}




\section{Supplementary Appendix}

\section{Table of contents}

Section S1. COVID-19 severity, criticality, and fatality classification

Section S2. Laboratory methods and variant ascertainment ….....................................................

Real-time reverse-transcription polymerase chain reaction testing .............................................. 3

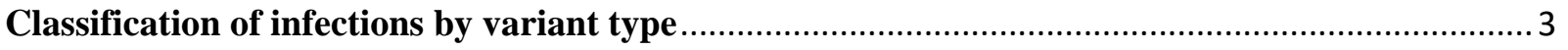

Table S1. STROBE checklist for case-control studies. ............................................................. 5

Figure S1. Flowchart describing the population selection process for investigating the effectiveness of the BNT162b2 and mRNA-1273 vaccines during the SARS-CoV-2 Omicron infection wave.

Table S2. Demographic characteristics of cases and controls in samples used to estimate the effectiveness of BNT162b2 and mRNA-1273 vaccines against symptomatic SARS-CoV-2 Omicron infection. The table includes samples used in the 1-month-after-second-dose analysis and 4-5-weeksafter-third-dose analysis for BNT162b2, and samples used in the 1-3-months-after-second-dose analysis and 4-5-weeks-after-third-dose analysis for mRNA-1273. These samples provide examples of the study population. Remaining samples for the different time-since-vaccination strata are

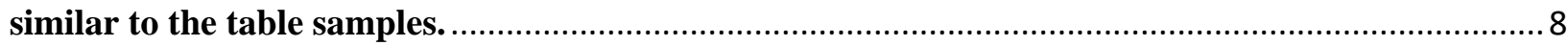

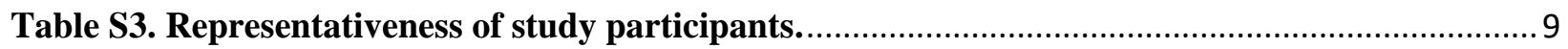

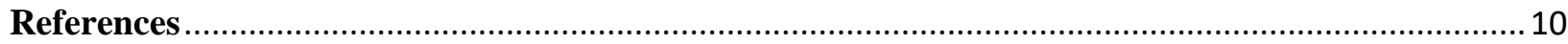


medRxiv preprint doi: https://doi.org/10.1101/2022.02.07.22270568; this version posted February 8, 2022. The copyright holder for this preprint (which was not certified by peer review) is the author/funder, who has granted medRxiv a license to display the preprint in perpetuity.

All rights reserved. No reuse allowed without permission.

\section{Section S1. COVID-19 severity, criticality, and fatality classification}

Severe Coronavirus Disease 2019 (COVID-19) disease was defined per the World Health

Organization (WHO) classification as a severe acute respiratory syndrome coronavirus 2 (SARS-

$\mathrm{CoV}-2$ ) infected person with "oxygen saturation of $<90 \%$ on room air, and/or respiratory rate of

$>30$ breaths/minute in adults and children $>5$ years old (or $\geq 60$ breaths/minute in children $<2$

months old or $\geq 50$ breaths/minute in children $2-11$ months old or $\geq 40$ breaths/minute in children

1-5 years old), and/or signs of severe respiratory distress (accessory muscle use and inability to

complete full sentences, and, in children, very severe chest wall indrawing, grunting, central

cyanosis, or presence of any other general danger signs)". ${ }^{1}$ Detailed WHO criteria for classifying

SARS-CoV-2 infection severity can be found in the WHO technical report. ${ }^{1}$

Critical COVID-19 disease was defined per WHO classification as a SARS-CoV-2 infected person with "acute respiratory distress syndrome, sepsis, septic shock, or other conditions that would normally require the provision of life sustaining therapies such as mechanical ventilation (invasive or non-invasive) or vasopressor therapy". ${ }^{1}$ Detailed WHO criteria for classifying SARS-CoV-2 infection criticality can be found in the WHO technical report. ${ }^{1}$

COVID-19 death was defined per WHO classification as "a death resulting from a clinically compatible illness, in a probable or confirmed COVID-19 case, unless there is a clear alternative cause of death that cannot be related to COVID-19 disease (e.g. trauma). There should be no period of complete recovery from COVID-19 between illness and death. A death due to COVID19 may not be attributed to another disease (e.g. cancer) and should be counted independently of preexisting conditions that are suspected of triggering a severe course of COVID-19". Detailed WHO criteria for classifying COVID-19 death can be found in the WHO technical report. ${ }^{2}$ 
medRxiv preprint doi: https://doi.org/10.1101/2022.02.07.22270568; this version posted February 8, 2022. The copyright holder for this preprint (which was not certified by peer review) is the author/funder, who has granted medRxiv a license to display the preprint in perpetuity.

All rights reserved. No reuse allowed without permission.

\section{Section S2. Laboratory methods and variant ascertainment}

\section{Real-time reverse-transcription polymerase chain reaction testing}

Nasopharyngeal and/or oropharyngeal swabs were collected for PCR testing and placed in Universal Transport Medium (UTM). Aliquots of UTM were: extracted on a QIAsymphony platform (QIAGEN, USA) and tested with real-time reverse-transcription PCR (RT-qPCR) using TaqPath COVID-19 Combo Kits (Thermo Fisher Scientific, USA) on an ABI 7500 FAST (Thermo Fisher, USA); tested directly on the Cepheid GeneXpert system using the Xpert Xpress SARS-CoV-2 (Cepheid, USA); or loaded directly into a Roche cobas 6800 system and assayed with a cobas SARS-CoV-2 Test (Roche, Switzerland). The first assay targets the viral S, N, and ORF1ab gene regions. The second targets the viral $\mathrm{N}$ and E-gene regions, and the third targets the ORF1ab and E-gene regions.

All PCR testing was conducted at the Hamad Medical Corporation Central Laboratory or Sidra Medicine Laboratory, following standardized protocols.

\section{Classification of infections by variant type}

Surveillance for SARS-CoV-2 variants in Qatar is mainly based on viral genome sequencing and multiplex RT-qPCR variant screening ${ }^{3}$ of random positive clinical samples, ${ }^{4-9}$ complemented by deep sequencing of wastewater samples. ${ }^{6,10}$

A total of 315 random SARS-CoV-2-positive specimens collected between December 19, 2021 and January 22, 2022 were viral whole-genome sequenced on a Nanopore GridION sequencing device. Of these, $300(95.2 \%)$ were confirmed as Omicron infections and $15(4.8 \%)$ as Delta (B.1.617.2) ${ }^{11}$ infections. ${ }^{6,12}$ No Delta case was detected in the viral genome sequencing since January 8, 2022. 
medRxiv preprint doi: https://doi.org/10.1101/2022.02.07.22270568; this version posted February 8, 2022. The copyright holder for this preprint (which was not certified by peer review) is the author/funder, who has granted medRxiv a license to display the preprint in perpetuity.

All rights reserved. No reuse allowed without permission.

Additionally, a total of 1,315 random SARS-CoV-2-positive specimens collected between December 22, 2021 and January 1, 2022 were RT-qPCR genotyped. The RT-qPCR genotyping identified 1 B.1.617.2-like Delta case, 366 BA.1-like Omicron cases, 898 BA.2-like Omicron cases, and 50 were undetermined cases where the genotype could not be assigned.

The accuracy of the RT-qPCR genotyping was verified against either Sanger sequencing of the receptor-binding domain (RBD) of SARS-CoV-2 surface glycoprotein (S) gene, or by viral whole-genome sequencing on a Nanopore GridION sequencing device. From 147 random SARS-CoV-2-positive specimens all collected in December of 2021, RT-qPCR genotyping was able to assign a genotype in 129 samples. The agreement between RT-qPCR genotyping and sequencing was $100 \%$ for Delta $(n=82), 100 \%$ for Omicron BA.1 $(n=18)$, and $93 \%$ for Omicron BA.2 (27 of 29 were correctly assigned to BA.2 and remaining 2 specimens genotyped as BA.2 were B.1.617.2 by sequencing). Of the remaining 18 specimens: 10 failed PCR amplification and sequencing, 8 could not be assigned a genotype by RT-qPCR ( 4 of 8 were B.1.617.2 by sequencing, and the remaining 4 failed sequencing). All the variant RT-qPCR genotyping was conducted at the Sidra Medicine Laboratory following standardized protocols.

The large Omicron-wave exponential-growth phase in Qatar started on December 19, 2021 and peaked in mid-January, 2022..$^{6,12,13}$ The study duration coincided with the intense Omicron wave where Delta incidence was limited and contributed less than $10 \%$ of cases. Accordingly, any PCR-positive test during the study duration, between December 23, 2021 and February 2, 2022, was used as a proxy for Omicron infection. Of note that the study duration started on December 23, 2021, and not on December 19, 2021, to minimize the occurrence of residual Delta incidence during the first few days of the Omicron wave. 
Table S1. STROBE checklist for case-control studies.

\begin{tabular}{|c|c|c|c|}
\hline & $\begin{array}{c}\text { Item } \\
\text { No }\end{array}$ & Recommendation & Main text page \\
\hline \multirow[t]{2}{*}{$\begin{array}{l}\text { Title and } \\
\text { abstract }\end{array}$} & \multirow[t]{2}{*}{1} & $\begin{array}{l}\text { (a) Indicate the study's design with a commonly used term in the title or the } \\
\text { abstract }\end{array}$ & Abstract \\
\hline & & $\begin{array}{l}\text { (b) Provide in the abstract an informative and balanced summary of what was } \\
\text { done and what was found }\end{array}$ & Abstract \\
\hline \multicolumn{4}{|c|}{ avic are } \\
\hline $\begin{array}{l}\text { Background/rati } \\
\text { onale }\end{array}$ & 2 & $\begin{array}{l}\text { Explain the scientific background and rationale for the investigation being } \\
\text { reported }\end{array}$ & Introduction \\
\hline Objectives & 3 & State specific objectives, including any prespecified hypotheses & Introduction \\
\hline \multicolumn{4}{|c|}{ (20) } \\
\hline Study design & 4 & Present key elements of study design & $\begin{array}{l}\text { Methods ('Study population, } \\
\text { data sources, and study design') }\end{array}$ \\
\hline Setting & 5 & $\begin{array}{l}\text { Describe the setting, locations, and relevant dates, including periods of } \\
\text { recruitment, exposure, follow-up, and data collection }\end{array}$ & $\begin{array}{l}\text { Methods ('Study population, } \\
\text { data sources, and study design') } \\
\text { \& Supp. Figure S1 }\end{array}$ \\
\hline \multirow[t]{2}{*}{ Participants } & \multirow[t]{2}{*}{6} & $\begin{array}{l}\text { (a) Give the eligibility criteria, and the sources and methods of case } \\
\text { ascertainment and control selection. Give the rationale for the choice of cases } \\
\text { and controls }\end{array}$ & \multirow[t]{2}{*}{$\begin{array}{l}\text { Methods ('Study population, } \\
\text { data sources, and study design') } \\
\text { \& Supp. Figure S1 }\end{array}$} \\
\hline & & $\begin{array}{l}\text { (b) For matched studies, give matching criteria and the number of controls per } \\
\text { case }\end{array}$ & \\
\hline Variables & 7 & $\begin{array}{l}\text { Clearly define all outcomes, exposures, predictors, potential confounders, and } \\
\text { effect modifiers. Give diagnostic criteria, if applicable }\end{array}$ & $\begin{array}{l}\text { Methods ('Study population, } \\
\text { data sources, and study design' } \\
\& \text { 'Statistical analysis'), Supp. } \\
\text { Sections S1 \& S2, \& Supp. } \\
\text { Figure S1 }\end{array}$ \\
\hline $\begin{array}{l}\text { Data sources/ } \\
\text { measurement }\end{array}$ & 8 & $\begin{array}{l}\text { For each variable of interest, give sources of data and details of methods of } \\
\text { assessment (measurement). Describe comparability of assessment methods if } \\
\text { there is more than one group }\end{array}$ & $\begin{array}{c}\text { Methods ('Study population, } \\
\text { data sources, and study design' } \\
\text { \& 'Statistical analysis') \& Supp. } \\
\text { Table S2 }\end{array}$ \\
\hline Bias & 9 & Describe any efforts to address potential sources of bias & $\begin{array}{l}\text { Methods ('Study population, } \\
\text { data sources, and study design' } \\
\text { \& 'Statistical analysis') }\end{array}$ \\
\hline Study size & 10 & Explain how the study size was arrived at & Supp. Figure S1 \\
\hline $\begin{array}{l}\text { Quantitative } \\
\text { variables }\end{array}$ & 11 & $\begin{array}{l}\text { Explain how quantitative variables were handled in the analyses. If applicable, } \\
\text { describe which groupings were chosen and why }\end{array}$ & $\begin{array}{c}\text { Methods ('Study population, } \\
\text { data sources, and study design' } \\
\text { \& 'Statistical analysis') \& Supp. } \\
\text { Table S2 }\end{array}$ \\
\hline \multirow[t]{5}{*}{$\begin{array}{l}\text { Statistical } \\
\text { methods }\end{array}$} & \multirow[t]{5}{*}{12} & $\begin{array}{l}\text { (a) Describe all statistical methods, including those used to control for } \\
\text { confounding }\end{array}$ & Methods ('Statistical analysis') \\
\hline & & (b) Describe any methods used to examine subgroups and interactions & Methods ('Statistical analysis') \\
\hline & & (c) Explain how missing data were addressed & $\begin{array}{l}\text { NA, see Methods ('Study } \\
\text { population, data sources, and } \\
\text { study design') }\end{array}$ \\
\hline & & (d) If applicable, explain how matching of cases and controls was addressed & $\begin{array}{l}\text { Methods ('Study population, } \\
\text { data sources, and study design' } \\
\text { \& 'Statistical analysis') }\end{array}$ \\
\hline & & (e) Describe any sensitivity analyses & $\begin{array}{l}\text { NA, see Discussion ('Caveats } \\
\text { and limitations') }\end{array}$ \\
\hline
\end{tabular}

\begin{tabular}{|c|c|c|c|}
\hline \multirow[t]{3}{*}{ Participants } & \multirow[t]{3}{*}{13} & $\begin{array}{l}\text { (a) Report numbers of individuals at each stage of study-eg numbers } \\
\text { potentially eligible, examined for eligibility, confirmed eligible, included in the } \\
\text { study, completing follow-up, and analysed }\end{array}$ & \multirow[t]{3}{*}{ Supp. Figure S1 } \\
\hline & & (b) Give reasons for non-participation at each stage & \\
\hline & & (c) Consider use of a flow diagram & \\
\hline \multirow[t]{2}{*}{ Descriptive data } & \multirow[t]{2}{*}{14} & $\begin{array}{l}\text { (a) Give characteristics of study participants (eg demographic, clinical, social) } \\
\text { and information on exposures and potential confounders }\end{array}$ & Supp. Tables S2-S3 \\
\hline & & $\begin{array}{l}\text { (b) Indicate number of participants with missing data for each variable of } \\
\text { interest }\end{array}$ & $\begin{array}{l}\text { NA, see Methods ('Study } \\
\text { population, data sources, and } \\
\text { study design') }\end{array}$ \\
\hline Outcome data & 15 & Report numbers in each exposure category, or summary measures of exposure & Results, Figure 1, \& Tables 1-2 \\
\hline \multirow[t]{2}{*}{ Main results } & \multirow[t]{2}{*}{16} & $\begin{array}{l}\text { (a) Give unadjusted estimates and, if applicable, confounder-adjusted estimates } \\
\text { and their precision (eg, 95\% confidence interval). Make clear which } \\
\text { confounders were adjusted for and why they were included }\end{array}$ & Results, Figure 1, \& Tables 1-2 \\
\hline & & (b) Report category boundaries when continuous variables were categorized & Supp. Table S2 \\
\hline
\end{tabular}


medRxiv preprint doi: https://doi.org/10.1101/2022.02.07.22270568; this version posted February 8, 2022. The copyright holder for this preprint (which was not certified by peer review) is the author/funder, who has granted medRxiv a license to display the preprint in perpetuity.

All rights reserved. No reuse allowed without permission.

\begin{tabular}{lclc}
\hline & & $\begin{array}{l}\text { (c) If relevant, consider translating estimates of relative risk into absolute risk } \\
\text { for a meaningful time period }\end{array}$ & NA \\
\hline Other analyses & 17 & $\begin{array}{l}\text { Report other analyses done - eg analyses of subgroups and interactions, and } \\
\text { sensitivity analyses }\end{array}$ & $\begin{array}{c}\text { NA, see Discussion ('Caveats } \\
\text { and limitations') }\end{array}$ \\
\hline Discussion & & & Discussion, paragraph 1 \\
\hline Key results & 18 & Summarise key results with reference to study objectives & $\begin{array}{c}\text { Discussion ('Caveats and } \\
\text { limitations') }\end{array}$ \\
\hline Limitations & 19 & $\begin{array}{l}\text { Discuss limitations of the study, taking into account sources of potential bias or } \\
\text { imprecision. Discuss both direction and magnitude of any potential bias }\end{array}$ & Discussion, paragraph 1 \\
\hline Interpretation & 20 & $\begin{array}{l}\text { Give a cautious overall interpretation of results considering objectives, } \\
\text { limitations, multiplicity of analyses, results from similar studies, and other } \\
\text { relevant evidence }\end{array}$ & $\begin{array}{l}\text { Discuss the generalisability (external validity) of the study results } \\
\text { limitations') \& Supp. Table S3 }\end{array}$ \\
\hline Generalisability & 21 & & Acknowledgements \\
\hline Other information & 22 & $\begin{array}{l}\text { Give the source of funding and the role of the funders for the present study } \\
\text { and, if applicable, for the original study on which the present article is based }\end{array}$ & ('Caveats and \\
\hline Funding & &
\end{tabular}

Abbreviations: NA, not applicable; Supp. Supplementary Appendix. 


\section{Figure S1. Flowchart describing the population selection process for investigating the effectiveness of the BNT162b2 and mRNA-1273 vaccines during the SARS-CoV-2 Omicron infection wave.}
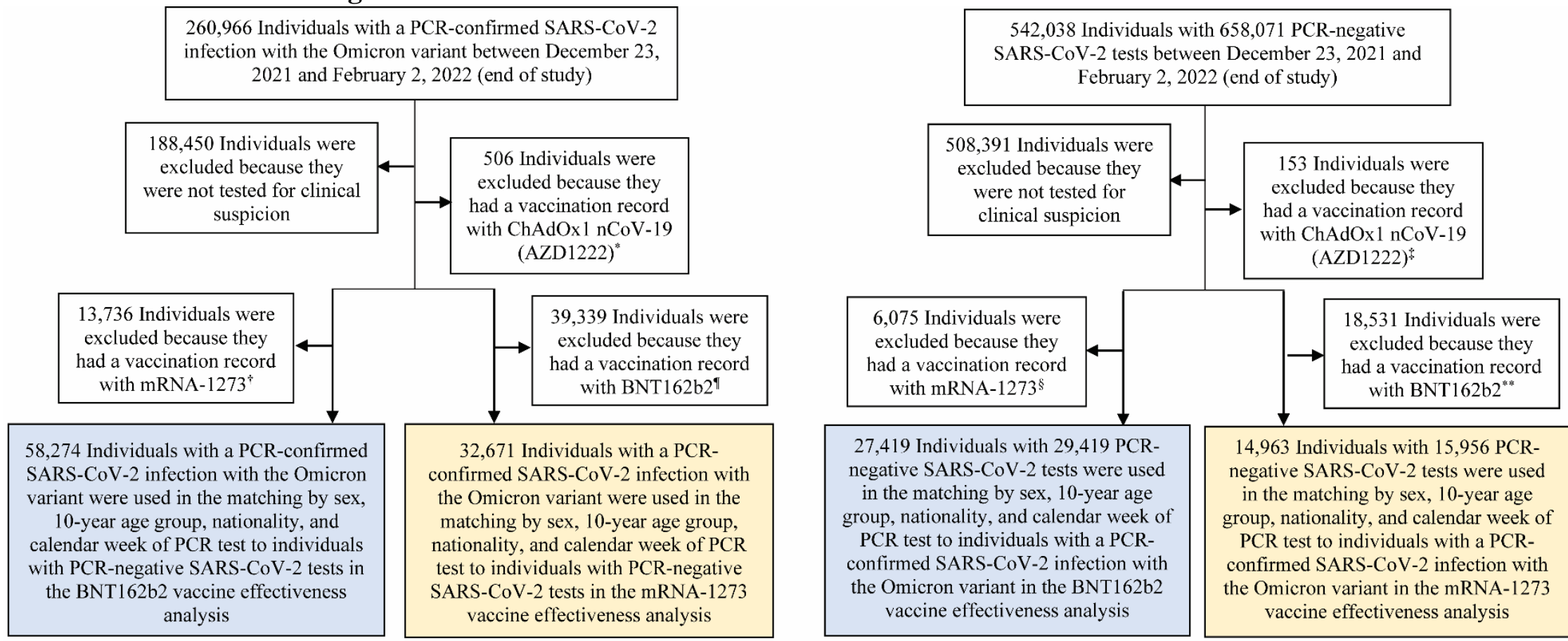

"Sample includes 3 persons who had another vaccination with mRNA-1273 and 95 persons who had another vaccination with BNT162b2.

Sample includes 8 persons who had another vaccination with BNT162b2.

Sample includes 1 person who had another vaccination with mRNA-1273 and 47 persons who had another vaccination with BNT162b2.

Sample includes 10 persons who had another vaccination with BNT162b2.

"Sample includes 6 persons who had another vaccination with mRNA-1273.

${ }^{* *}$ Sample includes 8 persons who had another vaccination with mRNA-1273.

Note: In each analysis for a specific time-since-vaccination stratum, we included only those vaccinated in this specific time-since-vaccination stratum and those unvaccinated (our reference group). Only matched pairs of PCR-positive and PCR-negative persons, in which both members of the pair were either unvaccinated or fell within each time-since-vaccination stratum have been included in the corresponding vaccine effectiveness estimate. Thus, the number of cases (and controls) varied across time-since-vaccination analyses. 
Table S2. Demographic characteristics of cases and controls in samples used to estimate the effectiveness of BNT162b2 and mRNA-1273 vaccines against symptomatic SARS-CoV-2 Omicron infection. The table includes samples used in the 1-monthafter-second-dose analysis and 4-5-weeks-after-third-dose analysis for BNT162b2, and samples used in the 1-3-months-aftersecond-dose analysis and 4-5-weeks-after-third-dose analysis for mRNA-1273. These samples provide examples of the study population. Remaining samples for the different time-since-vaccination strata are similar to the table samples.

\begin{tabular}{|c|c|c|c|c|c|c|c|c|c|c|c|c|}
\hline \multirow{4}{*}{ Characteristics } & \multicolumn{6}{|c|}{ BNT162b2 } & \multicolumn{6}{|c|}{ mRNA-1273 } \\
\hline & \multicolumn{3}{|c|}{ 1-month-after-second-dose } & \multicolumn{3}{|c|}{ 4-5-weeks-after-third-dose } & \multicolumn{3}{|c|}{ 1-3-months-after-second-dose } & \multicolumn{3}{|c|}{ 4-5-weeks-after-third-dose } \\
\hline & $\begin{array}{c}\text { Cases }^{*} \\
\text { (PCR- } \\
\text { positive) }\end{array}$ & $\begin{array}{l}\text { Controls }^{*} \\
\text { (PCR- } \\
\text { negative) }\end{array}$ & \multirow[t]{2}{*}{$\mathbf{S M D}^{\dagger}$} & $\begin{array}{c}\text { Cases }^{*} \\
\text { (PCR- } \\
\text { positive) }\end{array}$ & $\begin{array}{c}\text { Controls }^{*} \\
\text { (PCR- } \\
\text { negative) }\end{array}$ & \multirow[t]{2}{*}{$\mathbf{S M D}^{\dagger}$} & $\begin{array}{c}\text { Cases }^{*} \\
\text { (PCR- } \\
\text { positive) }\end{array}$ & $\begin{array}{c}\text { Controls }^{*} \\
\text { (PCR- } \\
\text { negative) }\end{array}$ & \multirow[t]{2}{*}{ SMD $^{\dagger}$} & $\begin{array}{c}\text { Cases }^{*} \\
\text { (PCR- } \\
\text { positive) }\end{array}$ & $\begin{array}{c}\text { Controls }^{*} \\
\text { (PCR- } \\
\text { negative) }\end{array}$ & \multirow[t]{2}{*}{ SMD } \\
\hline & $\mathrm{N}=13,042$ & $\mathrm{~N}=7,911$ & & $\mathrm{~N}=13,970$ & $\mathrm{~N}=8,543$ & & $\mathrm{~N}=12,841$ & $N=7,754$ & & $\mathrm{~N}=12,978$ & $\mathrm{~N}=\mathbf{7 , 8 4 5}$ & \\
\hline $\begin{array}{l}\text { Median age }(I Q R)- \\
\text { years }\end{array}$ & $12(6-32)^{\ddagger}$ & $12(5-32)^{\ddagger}$ & $0.01^{\S}$ & $18(6-34)^{\mathrm{II}}$ & $19(5-34)^{\mathbb{I I}}$ & $0.00^{\S}$ & $12(6-32)^{\ddagger}$ & $12(5-32)^{\ddagger}$ & $0.02^{\S}$ & $12(6-32)^{\pi}$ & $12(5-32)^{\mathbb{\pi}}$ & $0.01^{\S}$ \\
\hline Age group - no. $(\%)$ & & & & & & & & & & & & \\
\hline$<20$ years & $7,126(54.6)$ & $4,324(54.7)$ & & $7,101(50.8)$ & $4,307(50.4)$ & & $7,079(55.1)$ & $4,291(55.3)$ & & $7,080(54.6)$ & $4,292(54.7)$ & \\
\hline $20-29$ years & $2,090(16.0)$ & $1,254(15.9)$ & & $2,147(15.4)$ & $1,298(15.2)$ & & $2,034(15.8)$ & $1,213(15.6)$ & & $2,030(15.6)$ & $1,211(15.4)$ & \\
\hline $30-39$ years & $2,148(16.5)$ & $1,304(16.5)$ & & $2,524(18.1)$ & $1,560(18.3)$ & & $2,084(16.2)$ & $1,253(16.2)$ & & $2,168(16.7)$ & $1,302(16.6)$ & \\
\hline $40-49$ years & $870(6.7)$ & $534(6.8)$ & 0.01 & $1,160(8.3)$ & $731(8.6)$ & 0.01 & $856(6.7)$ & $523(6.7)$ & 0.01 & $877(6.8)$ & $540(6.9)$ & 0.01 \\
\hline $50-59$ years & 468 (3.6) & $290(3.7)$ & & $644(4.6)$ & $401(4.7)$ & & $463(3.6)$ & $280(3.6)$ & & $492(3.8)$ & $302(3.9)$ & \\
\hline $60-69$ years & 205 (1.6) & $126(1.6)$ & & $243(1.7)$ & $154(1.8)$ & & $197(1.5)$ & $120(1.6)$ & & $203(1.6)$ & $124(1.6)$ & \\
\hline $70+$ years & $135(1.0)$ & $79(1.0)$ & & $151(1.1)$ & $92(1.1)$ & & $128(1.0)$ & $74(1.0)$ & & $128(1.0)$ & $74(0.9)$ & \\
\hline \multicolumn{13}{|l|}{ Sex } \\
\hline Male & $6,827(52.4)$ & $4,168(52.7)$ & \multirow{2}{*}{0.01} & $7,379(52.8)$ & $4,552(53.3)$ & \multirow{3}{*}{0.01} & $6,748(52.6)$ & $4,108(53.0)$ & \multirow{3}{*}{0.01} & $6,853(52.8)$ & $4,171(53.2)$ & \multirow{3}{*}{0.01} \\
\hline Female & 6,215 (47.7) & $3,743(47.3)$ & & $6,591(47.2)$ & 3,991 (46.7) & & $6,093(47.5)$ & $3,646(47.0)$ & & $6,125(47.2)$ & $3,674(46.8)$ & \\
\hline Nationality ${ }^{* * *}$ & & & & & & & & & & & & \\
\hline Bangladeshi & $242(1.9)$ & $181(2.3)$ & \multirow{10}{*}{0.05} & $242(1.7)$ & $179(2.1)$ & \multirow{10}{*}{0.04} & $241(1.9)$ & $172(2.2)$ & \multirow{10}{*}{0.04} & 245 (1.9) & $172(2.2)$ & \multirow{10}{*}{0.04} \\
\hline Egyptian & $881(6.8)$ & $505(6.4)$ & & $960(6.9)$ & $555(6.5)$ & & $868(6.8)$ & $497(6.4)$ & & $873(6.7)$ & $501(6.4)$ & \\
\hline Filipino & $1,074(8.2)$ & $633(8.0)$ & & $1,316(9.4)$ & $795(9.3)$ & & $1,046(8.2)$ & $607(7.8)$ & & 1,085 & $639(8.2)$ & \\
\hline Indian & $1,732(13.3)$ & $1,044(13.2)$ & & $2,021(14.5)$ & 1,239 & & 1,701 & $1,023(13.2)$ & & 1,775 & $1,066(13.6)$ & \\
\hline Nepalese & $250(1.9)$ & $137(1.7)$ & & $256(1.8)$ & $143(1.7)$ & & $251(2.0)$ & $137(1.8)$ & & $255(2.0)$ & $140(1.8)$ & \\
\hline Pakistani & $550(4.2)$ & $322(4.1)$ & & $570(4.1)$ & $336(3.9)$ & & $543(4.2)$ & $316(4.1)$ & & $545(4.2)$ & $316(4.0)$ & \\
\hline Qatari & $4,382(33.6)$ & $2,601(32.9)$ & & $4,475(32.0)$ & $2,674(31.3)$ & & $4,284(33.4)$ & $2,541(32.8)$ & & $4,300(33.1)$ & $2,551(32.5)$ & \\
\hline Sri Lankan & $163(1.3)$ & $100(1.3)$ & & $170(1.2)$ & $104(1.2)$ & & $160(1.3)$ & $98(1.3)$ & & $155(1.2)$ & $95(1.2)$ & \\
\hline Sudanese & $631(4.8)$ & $381(4.8)$ & & $660(4.7)$ & $395(4.6)$ & & $630(4.9)$ & $378(4.9)$ & & $630(4.9)$ & $377(4.8)$ & \\
\hline Other nationalities ${ }^{\dagger \dagger}$ & $3,137(24.1)$ & $2,007(25.4)$ & & $3,300(23.6)$ & $2,123(24.9)$ & & $3,117(24.3)$ & $1,985(25.6)$ & & $3,115(24.0)$ & $1,988(25.3)$ & \\
\hline
\end{tabular}

Abbreviations: IQR, interquartile range; PCR, polymerase chain reaction; SMD, standardized mean difference.

"Cases and controls were matched two-to-one by sex, 10-year age group, nationality, and calendar week of PCR test.

${ }^{\dagger} \mathrm{SMD}$ is the difference in the mean of a covariate between groups divided by the pooled standard deviation. An $\mathrm{SMD}<0.1$ indicates adequate matching.

With the high vaccine coverage in Qatar $(>80 \%)$, the majority of those unvaccinated (reference group) were children or young persons, and thus the young median age in this study sample. For the same reason, most of those in the 1-month-after-second-dose stratum in the BNT162b2 analysis and in the 1-3-months-after-second-dose stratum in the mRNA-1273 analysis were children or adolescents as the majority of adults received their second dose months earlier.

${ }^{\circledR} \mathrm{S} M \mathrm{C}$ is for the mean difference between groups divided by the pooled standard deviation.

"With the high vaccine coverage in Qatar (>80\%), the majority of those unvaccinated (reference group) were children or young persons, and thus the young median age in this study sample.

"Nationalities were chosen to represent the most populous groups in Qatar.

"Nationalities were chosen to represent the most populous groups in Qatar. analysis and 55 other nationalities in the 4-5-weeks-after-third-dose analysis for mRNA-1273. 
Table S3. Representativeness of study participants.

\begin{tabular}{|c|c|}
\hline \multicolumn{2}{|l|}{ Category } \\
\hline Disease, problem, or condition under investigation & $\begin{array}{l}\text { Effectiveness and duration of protection of BNT162b2 and mRNA-1273 COVID-19 vaccines against } \\
\text { symptomatic infection with the SARS-CoV-2 Omicron variant and against COVID-19 hospitalization } \\
\text { and death due to Omicron variant infection. }\end{array}$ \\
\hline \multicolumn{2}{|l|}{ Special considerations related to } \\
\hline Sex and gender & $\begin{array}{l}\text { The effectiveness estimates were derived by comparing cases (PCR-positive for Omicron) and } \\
\text { controls (PCR-negative) at different times since vaccination. Cases and controls were exact-matched } \\
\text { by sex to control for potential differences in the risk of exposure to SARS-CoV-2 infection by sex. }\end{array}$ \\
\hline Age & $\begin{array}{l}\text { Cases and controls were exact-matched by } 10 \text {-year age group to control for potential differences in the } \\
\text { risk of exposure to SARS-CoV- } 2 \text { infection by age. Nonetheless, with the young population of Qatar, } \\
\text { our findings may not be generalizable to other countries where elderly citizens constitute a larger } \\
\text { proportion of the total population. }\end{array}$ \\
\hline Race or ethnicity group & $\begin{array}{l}\text { Cases and controls were exact-matched by nationality to control for potential differences in the risk of } \\
\text { exposure to SARS-CoV-2 infection by nationality. Nationality is associated with race and ethnicity in } \\
\text { the population of Qatar. }\end{array}$ \\
\hline Geography & $\begin{array}{l}\text { Cases and controls were exact-matched by nationality to control for potential differences in the risk of } \\
\text { exposure to SARS-CoV- } 2 \text { infection by nationality. Qatar has unusually diverse demographics in that } \\
89 \% \text { of the population are international expatriate residents coming from over } 150 \text { countries from all } \\
\text { world regions. }\end{array}$ \\
\hline Other considerations & $\begin{array}{l}\text { Individual-level data on co-morbid conditions were not available, but only a small proportion of the } \\
\text { study population may have had serious co-morbid conditions. Only } 9 \% \text { of the population of Qatar are } \\
\geq 50 \text { years of age (older age as proxy for co-morbidities). The national list of persons prioritized to } \\
\text { receive the vaccine during the first phase of vaccine roll-out included only } 19,800 \text { individuals of all } \\
\text { age groups with serious co-morbid conditions. }\end{array}$ \\
\hline Overall representativeness of this study & $\begin{array}{l}\text { The study was based on the total population of Qatar and thus the study population is broadly } \\
\text { representative of the diverse, by national background, but young and predominantly male, total } \\
\text { population of Qatar. While there could be differences in the risk of exposure to SARS-CoV-2 infection } \\
\text { by sex, age, and nationality, cases and controls were exact-matched by these factors to control for their } \\
\text { potential impact on our estimates for effectiveness of prior infection. Given that only } 9 \% \text { of the } \\
\text { population of Qatar are } \geq 50 \text { years of age and the limited proportion of the population with significant } \\
\text { co-morbidities, our estimates of effectiveness may not be generalizable to other countries where } \\
\text { elderly citizens constitute a larger proportion of the total population or where co-morbid conditions are } \\
\text { prevalent. With the high COVID-19 vaccine coverage in Qatar (>80\%), the majority of those } \\
\text { unvaccinated were children or young persons, and thus the reference group of those unvaccinated is } \\
\text { not representative of the total population demographics. However, matching by age was implemented } \\
\text { in all analyses to minimize potential bias arising from the young population structure of those } \\
\text { unvaccinated. }\end{array}$ \\
\hline
\end{tabular}


medRxiv preprint doi: https://doi.org/10.1101/2022.02.07.22270568; this version posted February 8, 2022. The copyright holder for this preprint (which was not certified by peer review) is the author/funder, who has granted medRxiv a license to display the preprint in perpetuity.

All rights reserved. No reuse allowed without permission.

\section{References}

1. World Health Organization. COVID-19 clinical management: living guidance. Available from: https://www.who.int/publications/i/item/WHO-2019-nCoV-clinical-2021-1. Accessed on: May 31, 2021. 2021.

2. World Health Organization. International guidelines for certification and classification (coding) of COVID-19 as cause of death. Available from: https://www.who.int/classifications/icd/Guidelines Cause of Death COVID-19-20200420EN.pdf?ua=1. Document Number: WHO/HO/DDI/DNA/CAT. Accessed on May 31, 2021. 2021.

3. Multiplexed RT-qPCR to screen for SARS-COV-2 B.1.1.7, B.1.351, and P.1 variants of concern V.3. dx.doi.org/10.17504/protocols.io.br9vm966. 2021. (Accessed June 6, 2021, at https://www.protocols.io/view/multiplexed-rt-qpcr-to-screen-for-sars-cov-2-b-1-1-br9vm966.)

4. Coyle PV, Kahlout RAE, Dargham SR, et al. Assessing the performance of a serological point-ofcare test in measuring detectable antibodies against SARS-CoV-2. medRxiv 2021:2021.02.04.21251126. 5. Chemaitelly H, Yassine HM, Benslimane FM, et al. mRNA-1273 COVID-19 vaccine effectiveness against the B.1.1.7 and B.1.351 variants and severe COVID-19 disease in Qatar. Nat Med 2021;27:161421.

6. Qatar viral genome sequencing data. Data on randomly collected samples.

https://www.gisaid.org/phylodynamics/global/nextstrain/. 2021. at https://www.gisaid.org/phylodynamics/global/nextstrain/.)

7. Benslimane FM, Al Khatib HA, Al-Jamal O, et al. One Year of SARS-CoV-2: Genomic Characterization of COVID-19 Outbreak in Qatar. Front Cell Infect Microbiol 2021;11:768883.

8. Hasan MR, Kalikiri MKR, Mirza F, et al. Real-Time SARS-CoV-2 Genotyping by High-Throughput Multiplex PCR Reveals the Epidemiology of the Variants of Concern in Qatar. Int J Infect Dis 2021;112:524.

9. Chemaitelly H, Tang P, Hasan MR, et al. Waning of BNT162b2 Vaccine Protection against SARSCoV-2 Infection in Qatar. N Engl J Med 2021;385:e83.

10. Saththasivam J, El-Malah SS, Gomez TA, et al. COVID-19 (SARS-CoV-2) outbreak monitoring using wastewater-based epidemiology in Qatar. Sci Total Environ 2021;774:145608.

11. World Health Organization. Tracking SARS-CoV-2 variants. Available from: https://www.who.int/en/activities/tracking-SARS-CoV-2-variants/. 2021.

12. Abu-Raddad LJ, Chemaitelly H, Ayoub HH, et al. Effectiveness of BNT162b2 and mRNA-1273 COVID-19 boosters against SARS-CoV-2 Omicron (B.1.1.529) infection in Qatar. medRxiv 2022:2022.01.18.22269452.

13. Altarawneh $\mathrm{H}$, Chemaitelly $\mathrm{H}$, Tang $\mathrm{P}$, et al. Protection afforded by prior infection against SARSCoV-2 reinfection with the Omicron variant. medRxiv In press at New England Journal of Medicine 2022:2022.01.05.22268782. 